\title{
Caput Succedaneum
}

National Cancer Institute

\section{Source}

National Cancer Institute. Caput Succedaneum. NCI Thesaurus. Code C87067.

A diffuse swelling of the scalp in a newborn, usually caused by the trauma of the scalp pushing through a narrowed cervix during birth. The swelling may extend across the midline of the scalp and may exhibit discoloration or bruising. 